\title{
PRODUKSI TABLET KOSMETIKA HERBAL BUAH TEMBESU UNTUK PERAWATAN KULIT DAN WAJAH
}

\section{HERBAL COSMETICS TABLET PRODUCTION FROM TEMBESU FRUIT FOR FACIAL DAN SKIN TREATMENT}

\author{
${ }^{1)}$ Addy Rachmat, ${ }^{2)}$ Julinar, ${ }^{3)}$ Desnelli, ${ }^{4)}$ Dasril Basir \\ 1,2,3,4) Jurusan Kimia, Fakultas Matematika dan Ilmu Pengetahuan Alam \\ Universitas Sriwijaya \\ Jalan Palembang-Prabumulih KM-35, Indralaya, Ogan Ilir, Sumatera Selatan, 30662 \\ *Email: debasril_chem@yahoo.com
}

\begin{abstract}
ABSTRAK
Buah Tembesu (Fragraea fragrans) memiliki metabolit sekunder asam ursolat, asam oleanolat, dan alkaloid gentianin. Senyawa metabolit sekunder ini telah diteliti dan dapat dimanfaatkan sebagai antiinflamasi, antikanker, antibakterial, antiaging, antifungal, antiviral, antialergik. Senyawa flavonoid juga teridentifikasi pada buah ini yang dapat digunakan sebagai antioksidan dan peredam radikal bebas penahan ageing; dan tanin trimer sebagai antikerut (antiwrinkle). Produk kosmetika herbal dari buah Tembesu telah diuji dan memberikan manfaat bagi peningkatan kesehatan kulit dan wajah. Warga di Desa Limbang Jaya II memiliki pemukiman yang kaya akan pohon Tembesu. Kegiatan pengabdian berupa penyuluhan dan pelatihan pembuatan kosmetika alam akan memberikan nilai lebih bagi hasil alam di desa tersebut. Produk kosmetika ini lebih disukai oleh remaja milenial saat ini karena tidak saja halal tetapi juga berkhasiat untuk perawatan tanpa ada efek samping karena hanya mengandung bahan alami.
\end{abstract}

Kata kunci: Tembesu; Kosmetika; Perawatan Kulit

\begin{abstract}
Tembesu fruit (Fragraea fragrans) contains several secondary metabolites such as ursolic acid, oleanolic acid, and gentianin alkaloids. These secondary metabolite compounds reported as antiinflammation, anti-cancer, antibacterial, anti-aging, antifungal, and anti-allergic. Flavanoid within this fruit was also identified and used as an anti-oxidant and free radical reducer, whereas trimer tannin can be used as anti-wrinkle. Herbal cosmetics production from Tembesu fruit has been tested dan provide benefits for skin and facial health improvement. Limbang Jaya II village is a settlement surrounded by a lot of Tembesu plant. Community development activity in such an area can be beneficial to increase value-added on local natural products. Counseling activity and training on herbal cosmetics production from Tembesu fruit will give the occupants health beneficiary and economic advantage from selling the products. Herbal cosmetics from Tembesu fruit attract the millennial generation due to its health benefit and no side effects because it is a natural product.
\end{abstract}

Keywords: Tembesu, Cosmetic, Skin Treatment

Submitted : 28 November 2019 Revision : 26 Agustus 2020 Accepted : 2 September 2020 


\section{PENDAHULUAN}

Kosmetika di era milenial ini adalah kebutuhan yang esensial bagi manusia, terutama kaum ibu dan remaja putri, setelah pangan, obat, vitamin, dan susu (Briliani, Safitri, \& Sudarno, 2016). Sesuai dengan obyek kegiatan ini maka analisis situasi dikelompokan atas dua aspek. Pertama, dalam rangka mengimplementasikan penemuan dan hasil penelitian tentang buah Tembesu yang kaya dengan kandungan asam ursolat dan asam oleanolat (López-Hortas, PérezLarrán, González-Muñoz, Falqué, \& Domínguez, 2018); senyawa organik yang telah teruji berkhasiat dan aman untuk bahan aktif kosmetika topikal (2 USA patents dan 3 Japan patents) (Basir, Hanafi, Julinar, Saputra, \& Wati, 2018). Oleh karena itu melalui kegiatan ini, disosialisasikan pembuatan tablet kosmetika herbal buah Tembesu untuk perawatan kulit (skincare). Kedua, secara botani tumbuhan Tembesu adalah a genuine plant of South Sumatra; artinya potensi keberadaanya adalah cukup tinggi tidak saja di hutan rawa Inderalaya maupun Sumatera Selatan, dan bahkan tersebar sampai dipantai Timur Sumatera (Bramasto \& Sudrajat, 2018). Berdasarkan dua keterangan di atas maka perlu disosialisasikan inovasi baru ini untuk mengaktualisasikan manfaat buah Tembesu bagi perawatan kulit dan wajah.

Sebenarnya secara nasional, industri kosmetika Indonesia merupakan industri yang ketergantungannya sangatlah tinggi terhadap bahan baku maupun kemasan impor. Oleh karena itu perlu ada kegiatan riset eksplorasi bahan aktif kosmetika dari tumbuhan asli Indonesia, seperti hasil penelitian pengusul tentang buah Tembesu ini, dan mempromosikan, menginplementasi kannya kepada masyarakat Limbang Jaya II, Kecamatan: Itanjung Batu, Kab: O. Ilir, khususnya bahkan akan berkelanjutan ketempat lain di Sumatra Selatan nantinya, mengigat potensialnya keberadaan buah pohon Tembesu ini di Hutan Rawa Pantai Timur Sumatra.

Alasan saintifik mengunakan bahan aktif kosmetika herbal perawatan kulit (skin care) adalah berdasarkan fakta uji preklinis yang terbukti bahwa buah Tembesu mengandung 3,05\% triterpenoid jenis ursolat dan oleanolat. Senyawa ini memiliki aktivitas farmakologis yang nyata sebagai anti bakteri (mengatasi jerawat), anti fungal, anti jamur (mengatasi panu dan keputihan), anti inflamasi (mengatasi radang dan jerawat), anti kanker leukemia L1210 (berkhasiat anti-tumor), dan sebagai pelindung kulit terhadap sinar ultraviolet sinar matahari (Basir, et al. 2012).

Secara fitokimia, tablet kosmetika buah Tembesu (Fragraea fragrans) mengandung beberapa metabolit sekunder. Di dalam sediaan mengandung asam ursolat; asam oleanolat sebagai antiinflamasi, antikanker, antibakterial, antiageing, antifungal, antiviral, antialergik; flavonoid sebagai antioksidan anti-ageing; tanin trimer sebagai antikerut (antiwrinkle); dan tepung organik.

Berdasarkan keterangan di atas maka Program Pengabdian Inovatif dan Aplikasi IPTEKS Paten ini adalah kelanjutan dari paten penulis yang berjudul Produksi kosmetika herbal dari buah Tembesu, Patent Number: IDP 000053691 (P00201507951, 2015). Oleh sebab itu dilaksanakan kegiatan pengabdian kepada masyarakat dengan luaran berupa produk tablet kosmetika herbal perawatan kulit dari buah Tembesu, sehingga nantinya dapat digunakan sebagai bedak dan masker perawatan kulit maupun wajah, dan bahkan sebagai produk kosmetika tradisional yang teruji preklinis sebagai home industry.

Kegiatan pengabdian ini dapat memberikan wawasan pengetahun, keterampilan warga dalam pengolahan buah Tembesu menjadi kosmetika herbal. Pemanfaatan lebih lanjut dapat terjadi melalui produksi kosmetika yang dapat memberikan keuntungan ekonomis dari 
pemanfaatan hasil alam yang belum tereksplorasi secara maksimal.

\section{METODE}

Untuk mencapai tujuan maka metode kegiatan pengabdian kepada masyarakat ini perlu dilakukan dari tahap 1 sampai 6.

Tahap 1. Memberikan penyuluhan tentang pemahaman potensi buah Tembesu di lingkungan sekitar peserta. Kegiatan ini bertujuan agar peserta memiliki kesadaran untuk menanam tumbuhan Tembesu karena tidak saja kandungan bioaktifnya bermanfaat untuk kosmetika perawatan kulit seperti anti jerawat, anti bakteri, anti fungal, antioksidan, dan antikerut pada kulit dan wajah, tetapi juga bagus sebagai tumbuhan pelindung dan penghasil osigen, daunya tidak mudah rontok dan kayunya bernilai ekonomis tinggi.

Tahap 2. Memberikan penyuluhan tentang persyaratan farmakologis suatu zat dapat dipakai sebagai kosmetika topikal (antibakteri, antijamur, antiinflamasi, antikanker leukemia); berkhasiat; dan tidak toksik serta tidak memberikan sifat gatal pada kulit.
Tahap 3. Memberikan peragaan, pelatihan dan praktek tentang cara pembuatan kosmetika herbal berkhasiat farmakologis, dan rasio perbandingan yang ideal antara tepung beras dan pasta buah Tembesu sebagai bahan bioaktif tablet kosmetika herbal, sesuai prosedur dan brosur penuntun pembuatan tablet kosmetika herbal.

Tahap 4. Memberikan penyuluhan dan bimbingan nyata dan konkrit tentang proses pencetakan tablet kosmetika herbal, sebelum dilakukan proses pengeringannya pada suhu kamar selama 4-7 hari.

Tahap 5. Memberikan penyuluhan tentang pentingnya memproduksi tablet kosmetika herbal yang higienis, kemasan yang menarik, dan diharuskan membuatkan etika cara memakai produk tersebut, seperti contoh produk jadi yang tim pelaksana berikan kepada masingmasing peserta sebanyak 2 sampai 4 kotak produk kosmetika herbal buah Tembesu per orang.

Tahap 6. Peserta diberi kesempatan untuk bertanya (diskusi) dan menyampaikan keinginan peserta kedepan sebagai tahapan evaluasi langsung

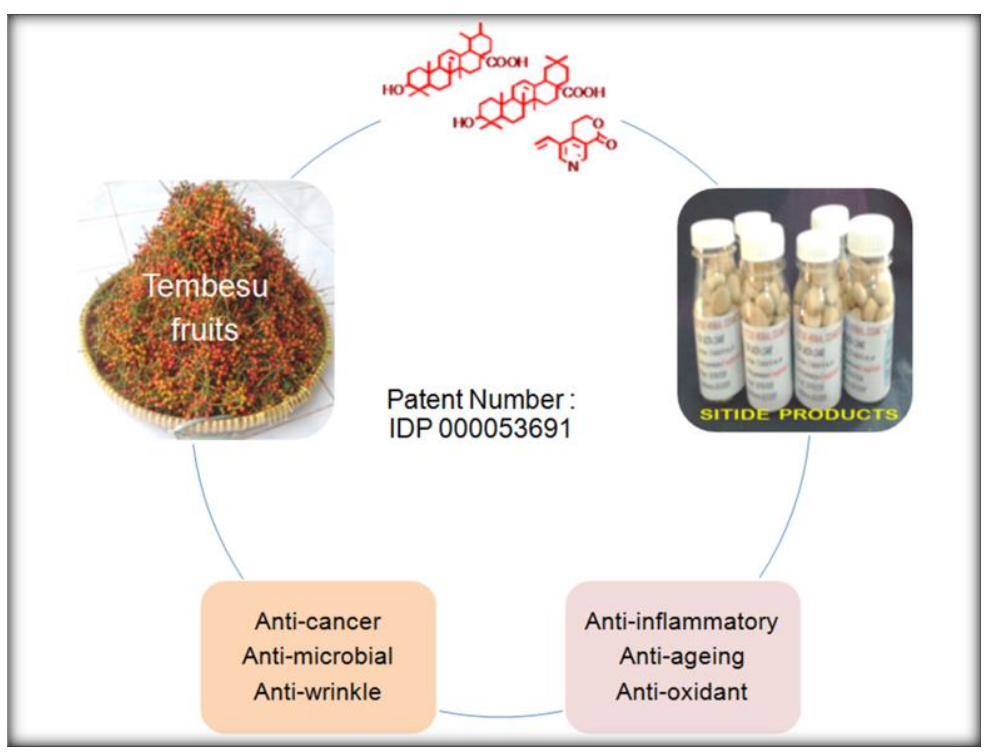

Gambar 1. Tablet kosmetika herbal buah tembesu dengan metabolit sekunder asam ursolat [isomernya asam oleanolat], flavonoid, dan tanin trimer 
ketertarikan peserta tentang produk kosmetika herbal buah Tembesu dalam pengabdian kepada masyarakat penguatan paten ini.

$$
\text { Untuk memantau tingkat }
$$

keberhasilan kegiatan ini dilakukan evaluasi :

1. Mengetahui sejauh mana materi dapat diserap oleh masyarakat

2. Mengetahui tingkat ketertarikan peserta akan inovasi ini

3. Mengetahui tingkat kemanjuran bedak ini dari pemakai (user).

\section{HASIL DAN PEMBAHASAN}

Kandungan material organik buah Tembesu adalah asam ursolat dan pasangan isomeriknya asam oleanolat. Secara tinjauan ilmiah, sampai saat ini telah ada bahkan lebih dari 200 artikel ilmiah terkait aktifitas biologis dan farmakologis asam ursolat (Mlala, Oyedeji, Gondwe, \& Oyedeji, 2019). Kosmetika dan beberapa produk terkait senyawa asam oleanolat maupun asam ursolat sebagai bahan bioaktif kosmetika dunia telah digunakan seperti di Amerika Serikat, dan India. Senyawa ini bahkan telah sebagai obat, suplemen lean body dari buah apel. Hal ini secara substansi, tablet kosmetika herbal buah Tembesu setara dengan substansi yang digunakan industri kosmetika di negara lain seperti USA, China, dan Malaysia (poulpender beauty) ataupun India sebagai produk teh. Berdasarkan keterangan ini masyarakat sasaran pengabdian ini telah percaya dan tidak ragu lagi untuk memakai dan memproduksi kosmetika herbal buah Tembesu untuk perawatan kulit maupun wajah maupun antusia mereka untuk berproduksi secara Usaha Kecil Menengah (UKM) karena khasiatnya setara dengan produk kosmetika resmi lainnya dan memiliki landasan ilmiah yang kuat (Gambar 1).

Hasil penelitian tim pelaksana yang dilakukan sebelumnya terhadap ekstrak dan molekul organik hasil isolasi, yaitu asam ursolat dan isomeriknya asam oleanolat telah teruji secara preklinis. Isolat terbukti berkhasiat sebagai antibakteri, antifungal, antiinflamasi, dan antikanker. Fakta ini menjadikan khalayak sasaran sangat antusias tentang khasiat kosmetika herbal buah Tembesu dan untuk dibimbing lebih lanjut sehingga dapat menjadi usaha rumah tangga atau UKM; dan dapat mendidik putra dan putri masyarakat sasaran untuk berwirausaha. Masyarakat sasaran dan perangkat desa Pulau Semambu sangat berminat atas kegiatan ini setelah mereka mengetahui khasiat kosmetika herbal buah Tembesu ini melalui testimoni.

Pelaksanaan pengabdian diawali dengan asesmen terhadap pemahaman warga tentang pemanfaatan buah Tembesu. Buah Tembesu selama ini tidak dimanfaatkan secara optimal dan hanya sekedar tumbuh liar tanpa ada upaya peningkatan manfaat secara ekonomis. Hasil asesmen terhadap warga ditunjukkan pada tabel 1 .

Tabel 1. Pre-asesmen pemahaman warga tentang pemanfaatan buah Tembesu

\begin{tabular}{|c|c|c|c|}
\hline \multirow{2}{*}{ No } & \multirow{2}{*}{ Keterangan } & \multicolumn{2}{|c|}{ Respon } \\
\hline & & $\mathrm{Ya}$ & Tidak \\
\hline 1 & $\begin{array}{l}\text { Mengetahui buah } \\
\text { Tembesu }\end{array}$ & $\checkmark$ & \\
\hline 2 & $\begin{array}{l}\text { Sudah memanfaatkan } \\
\text { buah Tembesu }\end{array}$ & & $\checkmark$ \\
\hline 3 & $\begin{array}{l}\text { Jika memanfaatkan, } \\
\text { apakah secara } \\
\text { ekonomi }\end{array}$ & - & - \\
\hline 4 & $\begin{array}{l}\text { Pernah membaca } \\
\text { tentang manfaat buah } \\
\text { Tembesu }\end{array}$ & & $\checkmark$ \\
\hline 5 & $\begin{array}{l}\text { Pernah mendapat } \\
\text { sosialisasi tentang } \\
\text { manfaat Tembesu }\end{array}$ & & $\checkmark$ \\
\hline 6 & $\begin{array}{l}\text { Bersedia mengikuti } \\
\text { program pemanfaatan } \\
\text { buah Tembesu }\end{array}$ & $\checkmark$ & \\
\hline
\end{tabular}


Addy Rachmat, Julinar, Desnelli, Dasril Basir Produksi Tablet Kosmetika Herbal Buah Tembesu Untuk Perawatan Kulit dan Wajah

Praktik Pembuatan Kosmetik Herbal

Tim pelaksana kegiatan

pengabdian memberikan pelatihan kepada khalayak yang hadir disertai praktik secara nyata dengan alat dan bahan yang telah disiapkan. Variabel pembuatan yang melibatkan waktu dapat disiasati dengan membawa bahan yang telah melewati tahapan tersebut seperti pengeringan selama 1 hari. Pemberian materi dibantu dengan slide proyektor dan mahasiswa yang langsung memberikan contoh pembuatan. Diskusi dan tanya jawab dilaksanakan secara spontan sehingga peserta pelatihan dapat melakukan proses pembuatan tanpa kendala yang berarti.
Uji Coba Pemakaian Kosmetika Herbal

Khalayak sasaran kegiatan selain mendapatkan sosialisasi dan pelatihan juga mendapatkan produk kosmetika herbal yang sudah jadi dan siap pakai. Tim mendorong peserta untuk menguji coba sendiri dan merasakan manfaatnya bagi kesehatan kulit dan wajah. Beberapa jenis kulit mungkin akan memberikan reaksi yang berbeda terhadap jenis kosmetika tertentu dan hal ini adalah sesuatu yang normal. Respon pengguna terhadap produk ini belum dapat dilakukan asesmen karena pemakaian memerlukan durasi waktu tertentu yang tidak dapat dicakup oleh kegiatan ini.

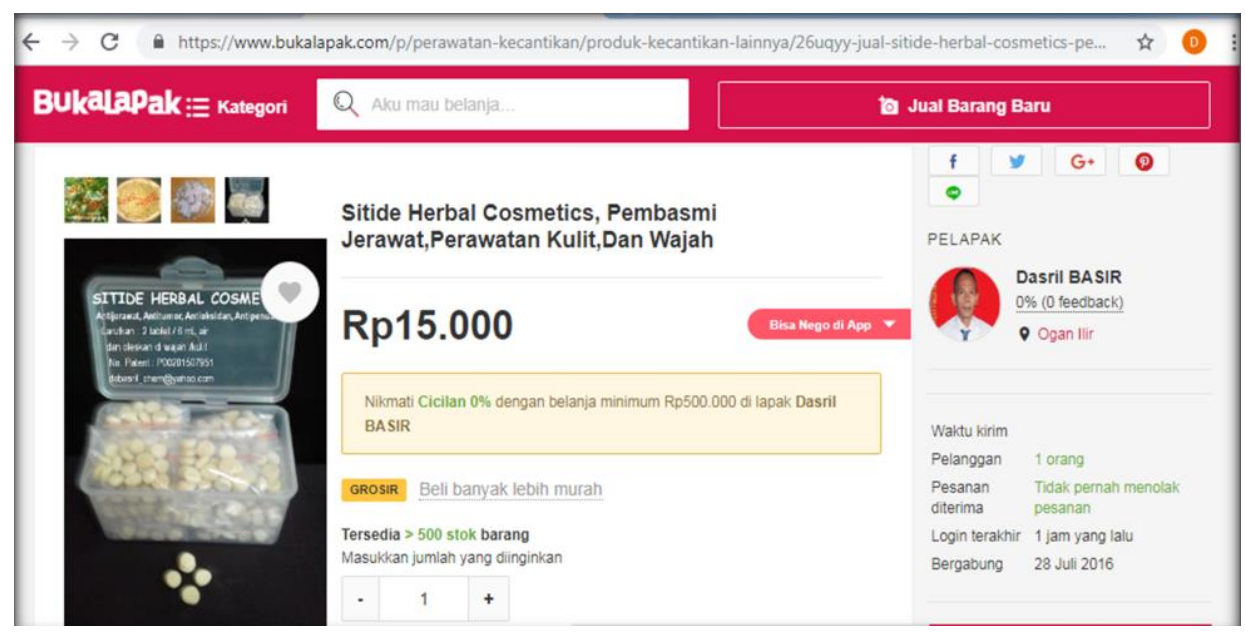

Gambar 2. UKM produk kosmetika herbal buah tembesu secara on line di bukalapak

Tim pelaksana pengabdian juga menguraikan beberapa testimoni dari individu yang telah merasakan manfaat dari kosmetika herbal yang telah diproduksi. Penggunaan kosmetika herbal ditekankan pada aspek perawatan dan kesehatan kulit sehingga pemakaiannya tidak seperti kosmetika biasa yang dapat digunakan setiap saat/waktu. Produk kosmetika herbal berupa bedak dari buah Tembesu ini juga telah dipasarkan secara daring melalui situs Bukalapak seperti dapat dilihat tangkapan layar pada Gambar 2.
Keberhasilan pemberian wawasan dan keterampilan khalayak sasaran diukur dengan melakukan post-test berupa kuesioner tertulis (Mulyana, 2016). Hasil post-test ini ditampilkan pada Tabel 2. 
Tabel 2. Hasil post-test kegiatan pelatihan pembuatan kosmetika herbal buah Tembesu

\begin{tabular}{|c|c|c|c|}
\hline \multirow{2}{*}{ No } & \multirow{2}{*}{ Uraian } & \multicolumn{2}{|c|}{ Respon } \\
\hline & & $\mathrm{Ya}$ & Tidak \\
\hline 1 & $\begin{array}{l}\text { Peserta memahami } \\
\text { manfaat kosmetika } \\
\text { herbal }\end{array}$ & $\checkmark$ & \\
\hline 2 & $\begin{array}{l}\text { Peserta mengetahui } \\
\text { cara pembuatan } \\
\text { kosmetika herbal }\end{array}$ & $\checkmark$ & \\
\hline 3 & $\begin{array}{l}\text { Peserta menguasai } \\
\text { metode pembuatan } \\
\text { kosmetika herbal }\end{array}$ & $\checkmark$ & \\
\hline 4 & $\begin{array}{l}\text { Peserta termotivasi } \\
\text { untuk memanfaatkan } \\
\text { buah Tembesu }\end{array}$ & $\checkmark$ & \\
\hline 5 & $\begin{array}{l}\text { Peserta ingin } \\
\text { memasarkan produk } \\
\text { secara daring }\end{array}$ & $\checkmark$ & \\
\hline
\end{tabular}

Penguasaan keterampilan pembuatan kosmetika herbal ini tidak akan maksimal tanpa dukungan alat dan bahan yang tersedia. Pada kesempatan ini tim telah menunjukkan bahan-bahan yang harus disiapkan dan dimana dapat memperolehnya. Peralatan yang diperlukan tidak terlalu sulit, namun tim juga telah memberikan bantuan peralatan berupa 1 unit blender yang dapat digunakan secara kolektif sebagai sarana produksi utama pembuatan kosmetika herbal ini.

\section{SIMPULAN}

Kegiatan pengabdian kepada masyarakat berupa sosialisasi dan pelatihan pembuatan kosmetika herbal telah berjalan dengan baik terlihat dari partisipasi warga mencapai 30-50 orang. Pemanfaatan bahan alam yang tumbuh di sekitar pemukiman warga memberikan komparatif dalam produksi barang yang dapat memberikan nilai ekonomis tinggi. Warga sasaran kegiatan telah mampu menyerap dan mempraktikan cara pembuatan dengan baik dan juga mendapatkan dukungan peralatan produksi dari tim kegiatan.

\section{UCAPAN TERIMA KASIH}

Penulis mengucapkan terima kasih kepada Lembaga Penelitian dan Pengabdian kepada Masyarakat Universitas Sriwijaya atas pendanaan kegiatan PPM Skema Inovasi berdasarkan kontrak nomor 0035.64/UN9/SB3.LP2M.PM/2019, 23 Agustus 2019. Ucapan terima kasih juga disampaikan kepada Kepala Desa Limbang Jaya II atas partisipasi aktifnya dalam kegiatan ini dengan mendorong warga ikut serta meningkatkan pemanfaatan buah Tembesu sebagai kosmetika herbal.

\section{DAFTAR PUSTAKA}

Basir, D., Hanafi, M., Julinar, J., Saputra, A., \& Wati, T. (2018). Free Solvent Amidation of Ursolic and Oleanolic Acids of Fagraea Fragrans Fruits: Their P-388 Antitumor Activity. Journal of Physics: Conference Series, $\quad 1095 . \quad 012006$ https://doi.org/10.1088/17426596/1095/1/012006

Basir, D. (2015). P00201507951. Indonesia.

Briliani, R.A., Safitri, D., \& Sudarno (2016). Analisis Kecenderungan Pemilihan Kosmetik Wanita di Kalangan Mahasiswi Jurusan Statistika Universitas Diponegoro menggunakan Bipot Komponen Utama. Jurnal Gaussian, 5(3), 545551.

https://doi.org/10.14710/j.gauss.v5i3.1 4711.

Bramasto, Y., \& Sudrajat, D.J. (2018). Karakteristik Morfo-Fisiologi Daun, Buah, dan Benih Tembesu (Fagraea fragrans Roxb.) dari Lima Populasi di Jawa Bagian Barat dan Sumatera Selatan. Jurnal Penelitian Hutan Tanaman, 15(1), 1-66. http://dx.doi.org/10.20886/jpht.2018.1 5.1.1-15 
López-Hortas, L., Pérez-Larrán, P., González-Muñoz, M. J., Falqué, E., \& Domínguez, H. (2018). Recent developments on the extraction and application of ursolic acid. A review. Food Research International, 103, 130-149.

https://doi.org/10.1016/j.foodres.2017. 10.028

Mlala, S., Oyedeji, A. O., Gondwe, M., \& Oyedeji, O. O. (2019, July 29). Ursolic Acid and Its Derivatives as Bioactive Agents. Molecules, 24(15),2751

https://doi.org/10.3390/molecules2415 2751.

Mulyana, N. (2016). Need Assessment Masyarakat Sekitar Kampus di Jatinangor. Share: Social Work Journal, $\quad 6(1), \quad 1-8$. https://doi.org/10.24198/share.v6i1.13 $\underline{143}$ 